\title{
NEUTRON SOURCES IN SPENT NUCLEAR FUEL OF RBMK-1500 TYPE REACTOR*
}

\author{
G. Adlys and D. Adlienè \\ Department of Physics, Kaunas University of Technology, Studentu 50, LT-51368 Kaunas, Lithuania \\ E-mail: Gediminas.Adlys@ktu.lt
}

Received 10 October 2003

\begin{abstract}
The main part of residual power of spent nuclear fuel depends on fission product radiation. The impact of neutron radiation on man and environment can be very significant, because the dosimetrical values from neutron sources become equivalent to those of photon irradiation when nuclear fuel is transported or stored for a long time in casks as in the case of Ignalina NPP. Mechanisms of neutron emission are discussed in the present paper and the results of calculations of spent nuclear fuel nuclide inventory using the codes APOLLO1 and REFACTN for the RBMK-1500 type reactor are presented. Results of calculations are used for the evaluation and assessment of neutron sources. It is shown that the main neutron sources in the spent nuclear fuel of the RBMK-1500 type reactor are ${ }^{242,243,244} \mathrm{Cm},{ }^{236,238,240} \mathrm{Pu},{ }^{232} \mathrm{U}$, and ${ }^{241} \mathrm{Am}$. It is determined that the emission of neutrons does not decrease with the time uniformly. Neutron emission due to the $(\alpha, \mathrm{n})$ reaction of ${ }^{228} \mathrm{Th}$ becomes significant after 50 years of cooling. The cooling time and burn-up of the nuclear fuel are the most important parameters that affect build-up of neutron sources.
\end{abstract}

Keywords: RBMK reactor, spent nuclear fuel, burn-up, neutron sources

PACS: 28.41.Ak, 28.41.Kw

\section{Introduction}

The assessment of neutron sources in spent nuclear fuel is very important measure from the point of view of radiation protection and nuclear safety.

Neutron emission is responsible for the additional doses to personnel during transportation and long-term dry storage of spent nuclear fuel. It is important for the evaluation of the criticality of the system.

The aim of this work was to numerically assess the neutron sources of spent nuclear fuel from the RBMK-1500 type reactor and to discuss the influence of different parameters on the build-up of these sources.

Calculations and modelling of parameters were performed using the codes APOLLO1 and REFACTN $[1,2]$.

\section{Modelling of nuclear fuel composition}

\subsection{Theoretical background}

A basic point for the assessment of neutron sources in spent nuclear fuel is the composition of initial nu-

\footnotetext{
* The report presented at the 35th Lithuanian National Physics Conference, 12-14 June 2003, Vilnius, Lithuania.
}

clear fuel and its evolution during operation of the reactor.

The composition of actinides in nuclear fuel changes during operation time of nuclear reactor. The new nuclides, such as $\mathrm{Np}, \mathrm{Pu}, \mathrm{Am}$, and $\mathrm{Cm}$, can be found in the nuclear fuel, which were not observed initially. Some of them are fissile, others act as the absorbers and can reduce reactivity of the reactor core. The main isotopes in the initial uranium-cycle nuclear fuel can be ${ }^{234} \mathrm{U},{ }^{235} \mathrm{U},{ }^{236} \mathrm{U}$, and ${ }^{238} \mathrm{U}$ depending on conditions of the fuel production. Uranium ${ }^{238} \mathrm{U}$ fissions only when it interacts with fast neutrons. Nevertheless, ${ }^{238} \mathrm{U}$ is a very important intermediate nuclide for the formation of ${ }^{239} \mathrm{Pu}$. Similar features are characteristic of the neutron capture chain which begins with ${ }^{239} \mathrm{Pu}$. After a capture of two neutrons, the fissile ${ }^{241} \mathrm{Pu}$ nuclide converts via beta decay to ${ }^{241} \mathrm{Am}$, which can act as a neutron absorber. Different behaviour of heavy nuclei requires setting up of their hierarchy. The criterion for the hierarchy of nuclides for the operating reactor is their reactivity.

When a neutron flux interacts with nuclei, the neutron capture reactions $(\mathrm{n}, \gamma)$ and $(\mathrm{n}, 2 \mathrm{n})$ occur and should be taken into account along with the sponta- 


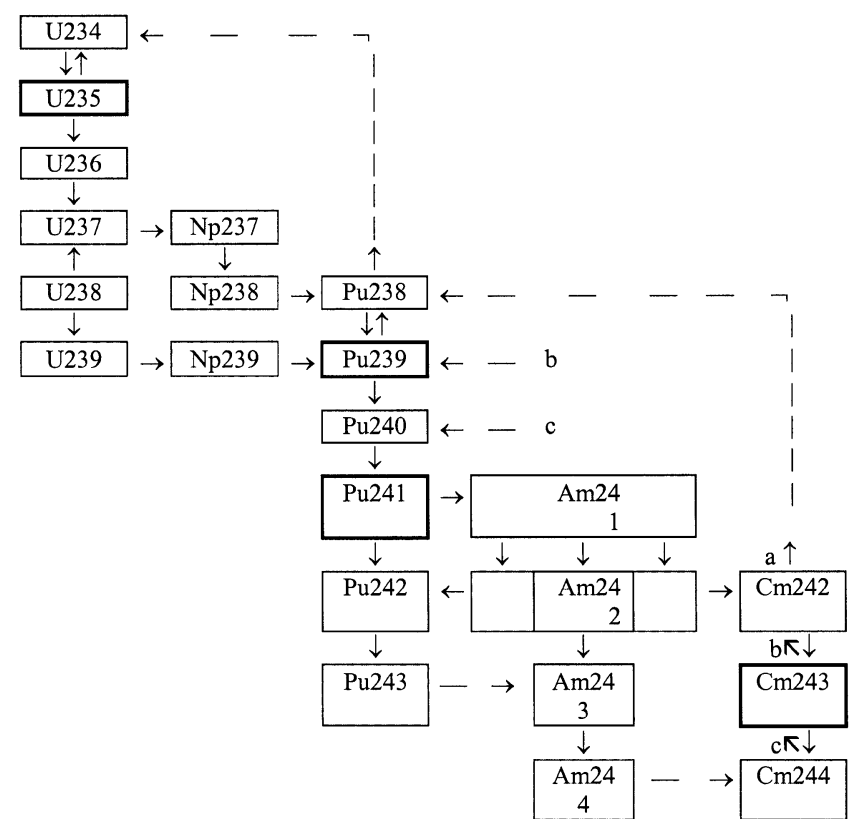

Fig. 1. Simplified evolution chain of uranium fuel [3].

neous fission or alpha and beta decay of nuclides in the nuclear fuel.

Simplified evolution chain of uranium fuel that includes reactions of neutron capture and alpha and beta decay of nuclides is presented in Fig. 1 [3]. The shaded, normal, and dashed boxes in Fig. 1 indicate the fissile nuclei, the nuclei that are stable for the interaction with slow neutrons, and the short-lifetime nuclei, respectively. The downward and upward arrows indicate the neutron capture $(\mathrm{n}, \gamma)$ and $(\mathrm{n}, 2 \mathrm{n})$ reactions, respectively. Horizontal arrows correspond to beta decay and the diagonal ones correspond to alpha decay of the short-lifetime nuclides. Curium isotopes ${ }^{242} \mathrm{Cm}$, ${ }^{243} \mathrm{Cm}$, and ${ }^{244} \mathrm{Cm}$ convert via alpha decay to plutonium ${ }^{238} \mathrm{Pu},{ }^{239} \mathrm{Pu}$, and ${ }^{240} \mathrm{Pu}$, respectively. Americium ${ }^{242} \mathrm{Am}$ is shown in three boxes because of different reaction output channels. After the capture of one neutron, ${ }^{241} \mathrm{Am}$ becomes either the ground state ${ }^{242} \mathrm{Am}$ in $11 \%$ cases or the metastable ${ }^{242 \mathrm{~m}} \mathrm{Am}$ in $89 \%$ cases. Americium ${ }^{242} \mathrm{Am}$ nuclei have two different beta decay channels. The $\beta^{-}$decay to ${ }^{242} \mathrm{Cm}$ occurs in $83 \%$ cases, while the electron capture with ${ }^{242} \mathrm{Pu}$ output is possible in $17 \%$ cases. The half-life of the processes is $16 \mathrm{~h}$. Metastable ${ }^{242 \mathrm{~m}} \mathrm{Am}$ nuclei have a long halflife (141 a) with respect to the neutron capture, which converts them to ${ }^{243} \mathrm{Am}$.

Concentrations of nuclides in the operating reactor depend on the neutron flux $\Phi(\mathbf{r}, E, t)$, on the initial values of the concentrations, and on the irradiation time (burn-up). After a capture of one neutron the $j$ th iso- tope irradiates $\gamma$ quantum and becomes the $(j+1)$ th isotope. The production rate of the $(j+1)$ th isotope can be expressed as [4]

$$
\begin{aligned}
& \frac{\partial n^{j+1}(\mathbf{r}, t)}{\partial t} \\
& =n^{j}(\mathbf{r}, t) \int_{0}^{\infty} \sigma_{\gamma}^{j}(E) \Phi(\mathbf{r}, E, t) \mathrm{d} E \\
& \quad-n^{j}(\mathbf{r}, t)\left[\int_{0}^{\infty} \sigma_{\mathrm{a}}^{j+1}(E) \Phi(\mathbf{r}, E, t) \mathrm{d} E+\lambda^{j+1}\right],
\end{aligned}
$$

where $\sigma_{\gamma}^{j}(E)$ is the $(\mathrm{n}, \gamma)$ reaction cross-section of the $j$ th isotope, $\sigma_{\mathrm{a}}^{j+1}(E)$ is the neutron absorption crosssection of the $(j+1)$ th isotope, and $\lambda^{j+1}$ is the decay constant of the $(j+1)$ th isotope.

The isotope index $j$ can be replaced by the combined one $j=a b$, where $a$ indicates the last numeral of the atomic number and $b$ corresponds to the last numeral of the mass number. In this case the production rate of the isotopes most important for the criticality of the reactor can be expressed as [3]

$$
\begin{aligned}
& \frac{\partial n^{25}}{\partial t}=\sigma_{\gamma}^{24} \Phi_{1} n^{24}-\sigma_{\mathrm{a}}^{25} \Phi_{1} n^{25}, \\
& \frac{\partial n^{28}}{\partial t}=-\sigma_{\mathrm{a}}^{28} \Phi_{1} n^{28} \\
& \frac{\partial n^{39}}{\partial t}=\lambda^{29} n^{29}-\left(\sigma_{\mathrm{a}}^{39} \Phi_{1} n^{24}+\lambda^{39}\right) n^{39},
\end{aligned}
$$

where the neutron flux $\Phi_{1}$ and the neutron absorption cross-section $\sigma_{a}^{j}$ depend on the position in reactor $\mathbf{r}$ and the irradiation time $t$ and are defined by the expressions

$$
\begin{aligned}
& \Phi_{1}=\Phi_{1}(\mathbf{r}, t)=\int_{0}^{\infty} \Phi(\mathbf{r}, E, t) \mathrm{d} E \\
& \sigma_{\mathrm{a}}^{j}=\sigma_{\mathrm{a}}^{j}(\mathbf{r}, t)=\frac{\int_{0}^{\infty} \sigma_{\mathrm{a}}^{j}(E) \Phi(\mathbf{r}, E, t) \mathrm{d} E}{\int_{0}^{\infty} \Phi(\mathbf{r}, E, t) \mathrm{d} E} .
\end{aligned}
$$

Fission of actinides becomes negligible, when the nuclear fuel is removed from the reactor. In such a case the terms, which include the neutron flux, drop out of Eq. (2) leaving only the decay terms. The spontaneous fission, which in principle can affect an evolution of nuclides, is not usually taken into account, because the half-time of the spontaneous fission is significantly longer than the decay half-time and, therefore, its influence on variation of the actinide concentrations is much smaller. Equations (2) can be solved implementing specific algorithms and the solutions are used as a 
database for modelling actinide behaviour in a nuclear reactor.

\subsection{Modelling parameters for the RBMK-1500 type reactor}

RBMK is a graphite moderated, boiling water cooled channel type reactor. The core is composed of $13.6 \mathrm{~mm}$ diameter fuel rods of low enriched uranium dioxide pellets enclosed in zirconium with $1 \%$ niobium cladding. Initial enrichment of nuclear fuel $\mathrm{UO}_{2}$ is $2.4 \%$. The fuel contains $0.41 \%$ of erbium as a burnable absorber. The rods are arranged in fuel assemblies that are placed inside pressure fuel channels. The fuel channels are installed in a graphite matrix and are cooled by water, which boils while passing the channels.

Every RBMK assembly is constituted by a set of 18 fuel elements arranged within two concentric rings. The first and the second rings contain 6 and 12 fuel rods, respectively. For calculations, the 18 fuel elements are shared into homogenized composition.

The model of 5 cylindrical zones is chosen for modelling of fuel assembly. The geometrical parameters of the fuel element are taken equal to given original values while the radii of the water-filled zone, fuel element channel, and graphite zone are calculated as $1 / 18$ part of the corresponding areas in the cross-section of fuel assembly.

The first zone $\left(r_{1}=0.566 \mathrm{~cm}, t_{1}=925^{\circ} \mathrm{C}\right)$ includes nuclear fuel with impurities, the second zone $\left(r_{2}=0.662 \mathrm{~cm}, t_{2}=312^{\circ} \mathrm{C}\right)$ corresponds to fuel element clad, the third $\left(r_{3}=0.919 \mathrm{~cm}, t_{3}=289^{\circ} \mathrm{C}\right)$ zone accounts for cooling water and spacer grids, while the fourth $\left(r_{4}=1.083 \mathrm{~cm}, t_{4}=305^{\circ} \mathrm{C}\right)$ and the fifth ( $r_{5}=3.309 \mathrm{~cm}, t_{5}=581^{\circ} \mathrm{C}$ ) ones correspond to the channel tube and graphite, respectively. Here $r_{n}$ is the radius and $t_{n}$ is the temperature of the $n$th zone.

The first zone includes an erbium absorber. Natural erbium consists of 6 isotopes, ${ }^{162} \mathrm{Er}(0.14 \%),{ }^{164} \mathrm{Er}$ (1.56\%), ${ }^{166} \mathrm{Er}(33.4 \%),{ }^{167} \mathrm{Er}(27.1 \%)$, and ${ }^{170} \mathrm{Er}$ (14.9\%). The most important role in neutron absorption is played by ${ }^{167} \mathrm{Er}$. Its neutron absorption crosssection is 10 times higher than that of ${ }^{166} \mathrm{Er}$. The erbium absorber in the nuclear fuel is an important factor which affects the neutron spectrum, inventory of actinides and their accumulation [5]. This is very important for interim spent nuclear fuel storage in CASTOR and CONSTOR casks.

Modelling of actinide accumulation in the RBMK-1500 type nuclear reactor was performed using APOLLO1 code. The program solves the Boltzmann equation using the collision probability technique and determines the nuclide concentrations and neutron related parameters, such as the flux and cross-sections, which are the functions of burn-up [1]. The concentrations of heavy nuclides calculated are further used as input parameters for REFACTN code, which evaluates neutron emission from neutron sources. REFACTN solves analytically the Bateman differential equations and calculates the concentrations of actinides and evolution of neutron sources during cooling of the reactor [2].

While modelling the parameters of the problem, it was assumed that the burn-up reaches $20 \mathrm{MW} \cdot \mathrm{d} / \mathrm{kg}$ at the power of $18 \mathrm{MW} / \mathrm{t}$.

\section{Assessment of neutron sources in nuclear fuel}

\subsection{Neutron emission from spent nuclear fuel}

Neutron emission from spent nuclear fuel depends on the build-up of heavy nuclei in fuel, which is a function of fuel burn-up, its initial content, its enrichment, and cooling time. The neutron emission $S$ from spent nuclear fuel consists of two parts [2,6]: (i) of the neutron emission caused by spontaneous fission of heavy nuclei and (ii) of the secondary emission of neutrons based on $(\alpha, \mathrm{n})$ reactions with oxygen in fuel oxide,

$$
{ }_{8}^{17,18} \mathrm{O}+{ }_{2}^{4} \mathrm{He} \rightarrow \mathrm{n}+{ }_{10}^{20,21} \mathrm{Ne} .
$$

Thus, the total neutron emission can be presented as

$$
S=C_{i}(t)\left[Y_{i}(\alpha, \mathrm{n})+Y_{i}(\mathrm{sf})\right],
$$

where $Y_{i}(\alpha, \mathrm{n})$ is the yield of $(\alpha, \mathrm{n})$ reaction of the $i$ th nucleus with oxygen in fuel oxide and $Y_{i}(\mathrm{sf})$ is the yield of spontaneous fission of the $i$ th nucleus. The yields can be expressed as

$$
Y_{i}(\alpha, \mathrm{n})=r(\alpha, \mathrm{n}) \lambda_{\alpha}, \quad Y_{i}(\mathrm{sf})=\nu \lambda_{\mathrm{sf}},
$$

where $r(\alpha, \mathrm{n})$ is the number of emitted neutrons due to $(\alpha, \mathrm{n})$ reaction with oxygen, $\lambda_{\alpha}$ is the alpha decay constant, $\nu$ is the number of neutrons emitted by spontaneous fission, and $\lambda_{\mathrm{sf}}$ is the constant of spontaneous fission of nuclei.

Figure 2 presents calculation results for the yield distributions of the spontaneous fission reactions of uranium isotopes in nuclear fuel and of the $(\alpha, \mathrm{n})$ reactions.

The contribution of nuclides to neutron emission is rather different and proportional to the yields and concentrations of the nuclides in spent nuclear fuel. Isotopes ${ }^{236} \mathrm{Pu},{ }^{232} \mathrm{U},{ }^{242 \mathrm{~m}} \mathrm{Am},{ }^{242} \mathrm{Pu},{ }^{242} \mathrm{Cm},{ }^{238} \mathrm{Pu}$, 


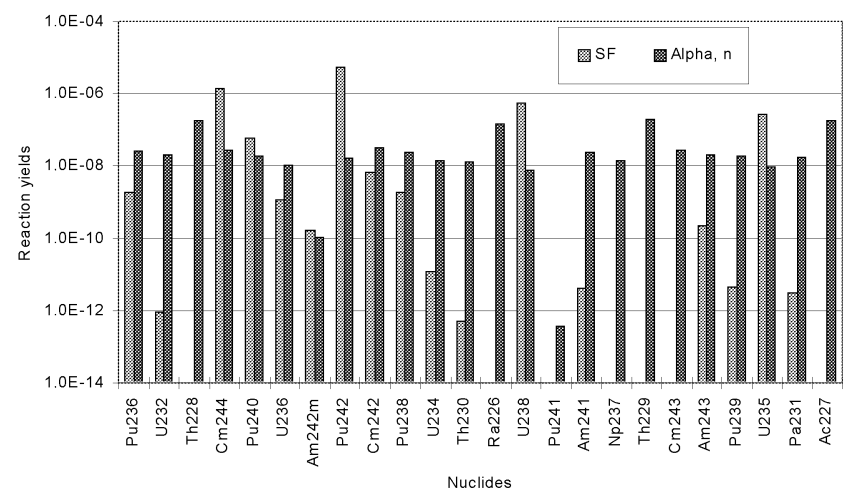

Fig. 2. Neutron yield distributions of spontaneous fission and of $(\alpha, \mathrm{n})$ reactions.

${ }^{234} \mathrm{U},{ }^{238} \mathrm{U},{ }^{241} \mathrm{Am},{ }^{244} \mathrm{Cm},{ }^{240} \mathrm{Pu},{ }^{236} \mathrm{U},{ }^{243} \mathrm{Am},{ }^{239} \mathrm{Pu}$, and ${ }^{235} \mathrm{U}$ represent both mechanisms of neutron emission, but ${ }^{228} \mathrm{Th},{ }^{241} \mathrm{Pu},{ }^{237} \mathrm{~Np},{ }^{243} \mathrm{Cm},{ }^{229} \mathrm{Th},{ }^{227} \mathrm{Ac}$, and ${ }^{226} \mathrm{Ra}$ are neutron sources with respect to $(\alpha, \mathrm{n})$ reactions with oxygen only.

\subsection{Neutron emission from initial nuclear fuel}

Neutron emission reactions in fresh, initial, nuclear fuel, which consists of $\mathrm{UO}_{2}$, are the same as in the spent nuclear fuel. The reactions are not intensive as long as concentrations of heavy nuclides in the fuel are low. Calculations show that the total neutron emission from $1 \mathrm{~kg}$ of $2.4 \%{ }^{235} \mathrm{U}$ enriched uranium fuel, which consists of ${ }^{234} \mathrm{U}$ and ${ }^{236} \mathrm{U}$ impurities, is only 14 neutrons/s. The fission neutrons make up $94.3 \%$ of the total emission and the neutrons emitted in $(\alpha, \mathrm{n})$ reactions with oxygen make up the $5.7 \%$ part. Intensity of neutron emission from the fresh nuclear fuel is almost independent of the time of storage and does not change during the first few hundreds of years. Some changes in the intensity of neutron emission can be observed for the nuclides, which are presented in initial decay chains, namely ${ }^{230} \mathrm{Th},{ }^{226} \mathrm{Ra},{ }^{231} \mathrm{~Pa}$, and ${ }^{227} \mathrm{Ac}$, if the storage time is comparable with the duration of geological storage. Influence of these nuclides on the total neutron emission is illustrated in Fig. 3. It can be shown that the ${ }^{232} \mathrm{U},{ }^{234} \mathrm{U}$, and ${ }^{236} \mathrm{U}$ impurities of the nuclear fuel are responsible for a slight increase of neutron emission.

\subsection{Influence of burn-up on neutron emission}

Concentrations of actinides vary in accordance with the burn-up of nuclear fuel. The process is related with the changes in the intensity of neutron emission. When the fuel burn-up increases, the emission intensity of

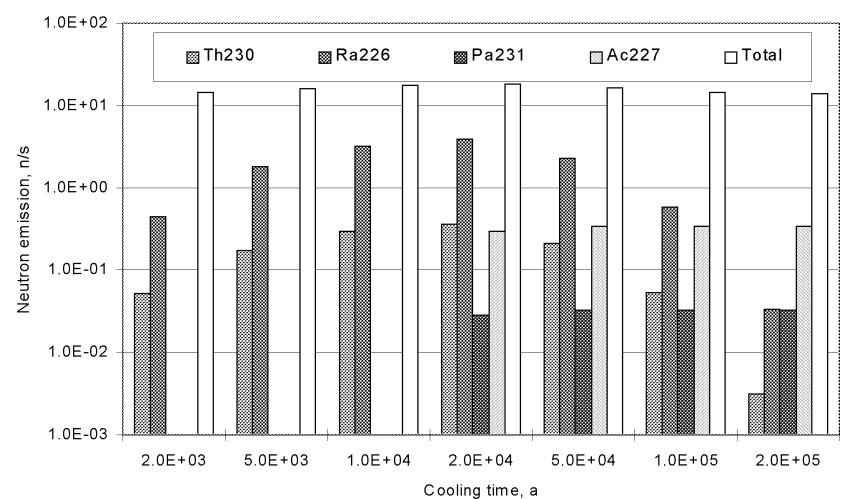

Fig. 3. Evolution of neutron yields from nuclides in fresh nuclear fuel with geological time.

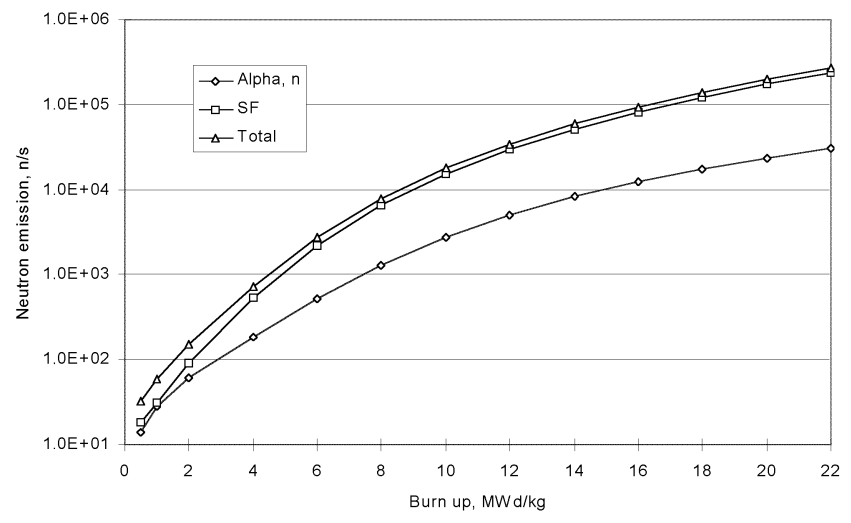

Fig. 4. Variation of neutron emission versus burn-up in uranium fuel.

neutrons from a mass unit of heavy metal increases as well due to an increase of intensities of both neutron emission reactions. Comparing the values of neutron emission intensity for $10 \mathrm{MW} \cdot \mathrm{d} / \mathrm{kg}$ and $20 \mathrm{MW} \cdot \mathrm{d} / \mathrm{kg}$ burn-up, one can evaluate that the total emission increases 11 times, while the partial emission channels due to the spontaneous fission and due to alpha particles increase 11.5 and 8.5 times, respectively. Dependences of both channels of neutron emission and of the total emission intensity on the burn-up at $0.1 \mathrm{~s}$ after stoppage of reactor are presented in Fig. 4. (The water density in the fuel channel was $68 \%$.) As is evidently seen from the figure, the spontaneous fission-induced neutron emission increases faster as compared to that due to $(\alpha, \mathrm{n})$ reactions.

Figure 5 presents the dependence of the total neutron emission intensity on the burn-up for different nuclides. As seen, the growth of emission intensity with the burnup differs for various nuclides.

Variations of neutron emission intensity versus burnup for different cooling times are presented in Fig. 6. 


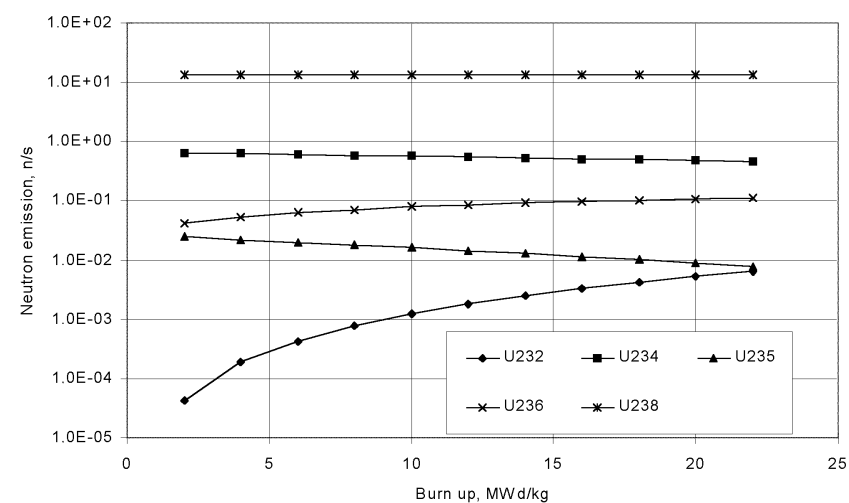

(a)

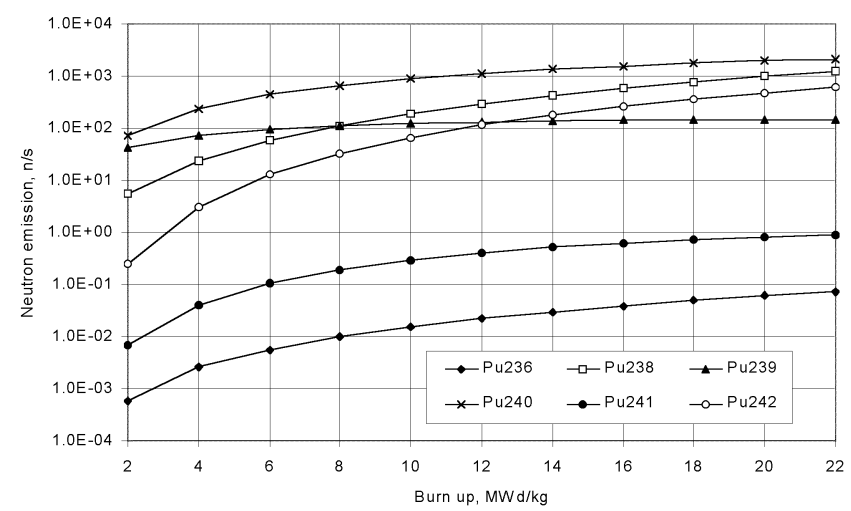

(b)

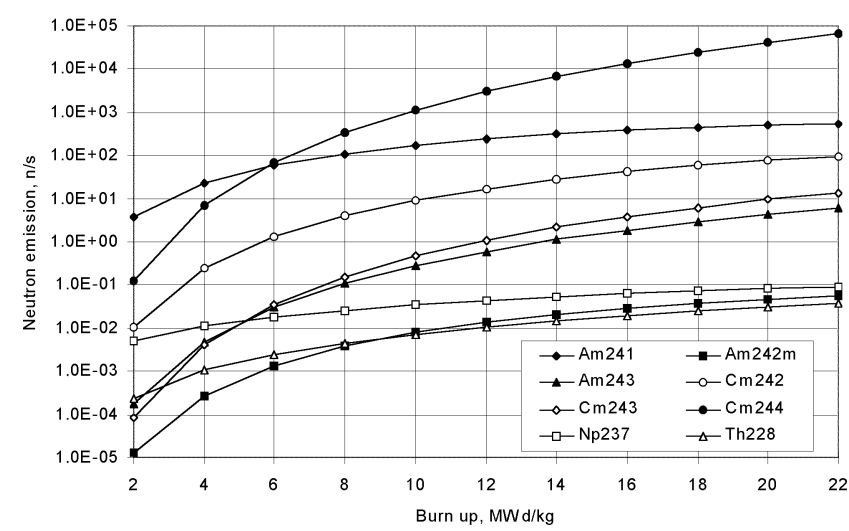

(c)

Fig. 5. Dependences of neutron emission on burn-up for (a) uranium isotopes, (b) plutonium isotopes, and (c) Am, Cm, Np, and Th nuclides.

\subsection{Influence of cooling time on neutron emission}

With an increase of the cooling time the neutron emission generally decreases. Variations of the nuclide number $C_{i}$ in decay chains are determined by the equation [2]

$$
\frac{\mathrm{d} C_{i}(t)}{\mathrm{d} t}=\sum_{i} C_{i}(t) \lambda_{k} b_{k \rightarrow i}-\lambda_{i} C_{i}(t)
$$

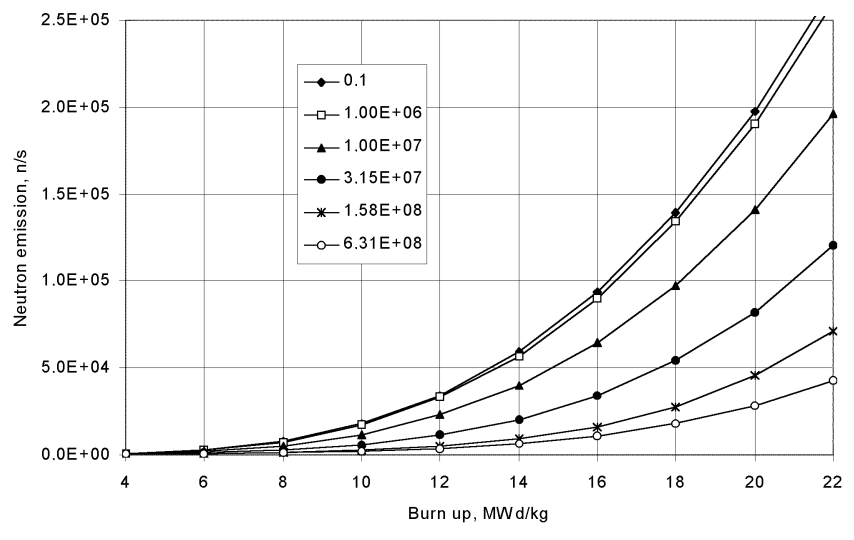

Fig. 6. Neutron emission versus burn-up for different cooling times.

where $\lambda_{k}$ and $\lambda_{i}$ are decay constants of the $k$ th and $i$ th nuclides, respectively, and $b_{k \rightarrow i}$ is the branching ratio.

For the initial spent nuclear fuel burn-up of $20 \mathrm{MW} \cdot \mathrm{d} / \mathrm{kg}$, the part of emitted neutrons due to spontaneous fission is $88 \%$ and that due to $(\alpha, \mathrm{n})$ reactions with oxygen is $12 \%$. After 5 years of cooling the spontaneous fission-induced emission becomes 2.3 times smaller and that due to $(\alpha, \mathrm{n})$ reactions reduces 3.7 times. The total neutron emission decreases 2.3 times in this period. Due to the different time dependences, the part of neutrons from spontaneous fission constitutes $92 \%$ after the period of 5 years and the part due to $(\alpha, \mathrm{n})$ reactions with oxygen makes up only $8 \%$. After the cooling period of 50 years (this time is proposed for the dry long-term storage of spent nuclear fuel in CONSTOR and CASTOR casks at Ignalina NPP) the intensity of total neutron emission decreases 5 times as compared with that from the initial spent nuclear fuel. Then the constituent parts of neutron emission make up $94 \%$ for spontaneous fission neutrons and $6 \%$ for $(\alpha, \mathrm{n})$ reaction neutrons. Figure 7 presents evolution of the total neutron emission and its constituent parts with the cooling time.

The most important changes during long-term cooling period occur for ${ }^{241} \mathrm{Pu},{ }^{242} \mathrm{Cm},{ }^{243} \mathrm{Cm}$, and ${ }^{244} \mathrm{Cm}$ isotopes. The concentrations of these isotopes decreases with time but the concentration of decay daughters such as ${ }^{241} \mathrm{Am},{ }^{238} \mathrm{Pu},{ }^{239} \mathrm{Pu}$, and ${ }^{240} \mathrm{Pu}$ increases. The most active sources of neutrons are ${ }^{242} \mathrm{Cm}$ and ${ }^{244} \mathrm{Cm}$ isotopes from the following decay chains:

$$
\begin{aligned}
{ }^{241} \mathrm{Pu}\left(\beta^{-}\right) & \rightarrow{ }^{241} \mathrm{Am}(\mathrm{n}, \gamma) \rightarrow{ }^{242} \mathrm{Am}\left(\beta^{-}\right) \\
& \rightarrow{ }^{242} \mathrm{Cm}, \\
{ }^{242} \mathrm{Pu}(\mathrm{n}, \gamma) & \rightarrow{ }^{243} \mathrm{Pu}\left(\beta^{-}\right) \rightarrow{ }^{243} \mathrm{Am}(\mathrm{n}, \gamma) \\
& \rightarrow{ }^{244} \mathrm{Am}\left(\beta^{-}\right) \rightarrow{ }^{244} \mathrm{Cm} .
\end{aligned}
$$




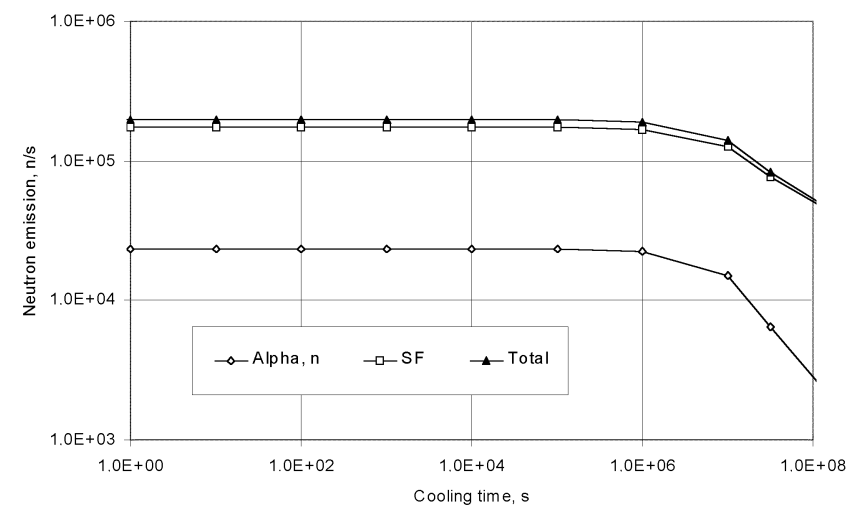

Fig. 7. Variation of the total neutron emission and its constituent parts versus cooling time.

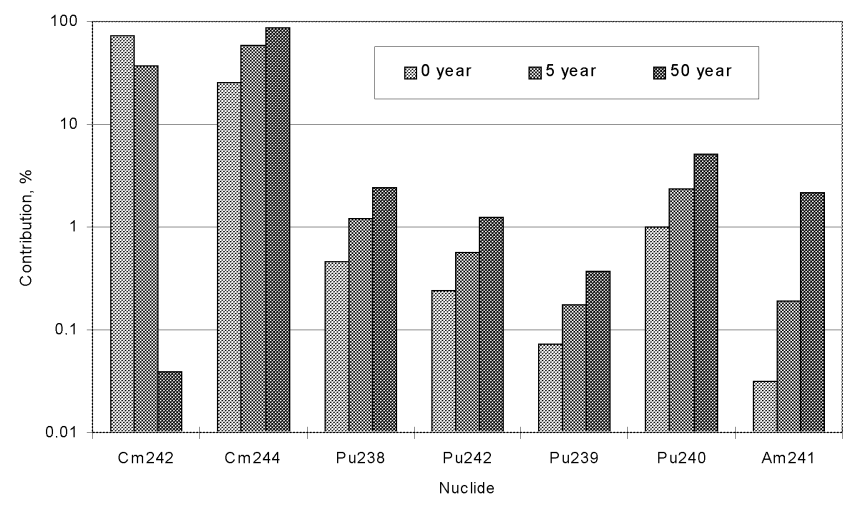

Fig. 8. Contribution of most active nuclides to the total neutron emission for different cooling times.

Their contribution to neutron emission (Fig. 8) as compared with all neutron sources is $73 \%$ for spontaneous fission neutrons and $25 \%$ for $(\alpha, \mathrm{n})$ reaction neutrons at $20 \mathrm{MW} \cdot \mathrm{d} / \mathrm{kg}$ burn-up of nuclear fuel and just after its removal from reactor. After 5 years of cooling the contribution of the nuclides constitutes $37 \%$ and $58 \%$ for spontaneous fission and $(\alpha, \mathrm{n})$ neutrons, respectively. After 50 years of cooling the nuclide contribution makes up $0.04 \%$ and $89 \%$ for spontaneous fission and $(\alpha, \mathrm{n})$ neutrons, respectively.

Other important active neutron emitters are ${ }^{238} \mathrm{Pu}$, ${ }^{239} \mathrm{Pu},{ }^{240} \mathrm{Pu},{ }^{242} \mathrm{Pu}$, and ${ }^{241} \mathrm{Am}$ nuclides. Their contribution to the neutron emission is presented in Fig. 8.

Variations of neutron emission with cooling time for different nuclides acting as the emission source are presented Fig. 9.

Most of the considered nuclides are produced directly in the operating reactor. Nevertheless, their influence on neutron emission depends on a genetic decay chain, on a position of the nuclide within the chain, and on the decay half-life. The half-life of the most active neutron emitter ${ }^{242} \mathrm{Cm}$ is relatively short, about

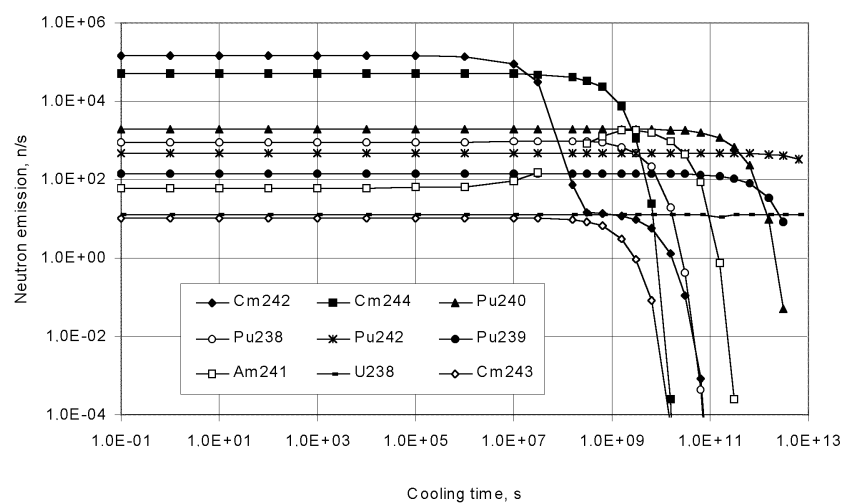

(a)

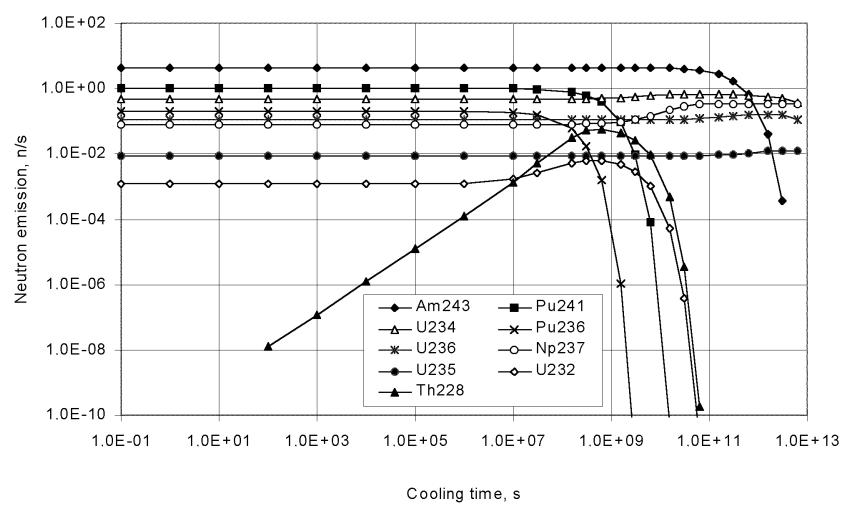

(b)

Fig. 9. Neutron emission versus cooling time for different nuclides ((a) stronger and (b) weaker emitters) acting as the emission sources.

163 days, however, the neutron emission from ${ }^{242} \mathrm{Cm}$ starts to decrease after few years. The slow-down of the process can be explained taking into account that new ${ }^{242} \mathrm{Cm}$ nuclei are produced in another decay chain

$$
{ }^{242 \mathrm{~m}} \mathrm{Am}(\gamma) \rightarrow{ }^{242} \mathrm{Am}\left(\beta^{-}\right) \rightarrow{ }^{242} \mathrm{Cm},
$$

which affects ${ }^{242} \mathrm{Cm}$ concentration after several tens of years.

The increase of ${ }^{241} \mathrm{Am}$ contribution (Fig. 9(a)) can be explained in a similar manner. It takes place when ${ }^{241} \mathrm{Pu}$ nuclide with the half-life of 14.35 year decays to ${ }^{241} \mathrm{Am}$.

Nonmonotonous variations of the ${ }^{232} \mathrm{U}$ and ${ }^{234} \mathrm{U}$ contributions to neutron emission (Fig. 9(b)) are related with the alpha decay of ${ }^{236} \mathrm{Pu}$ and decay of ${ }^{238} \mathrm{U}$, respectively. Maxima in the time dependences of neutron emission intensities, which are due to ${ }^{237} \mathrm{~Np}$ and ${ }^{234} \mathrm{U}$ nuclides (Fig. 9(b)), originate from the decay chains

$$
\begin{aligned}
& { }^{241} \mathrm{Pu} \rightarrow{ }^{241} \mathrm{Am} \rightarrow{ }^{237} \mathrm{~Np}, \\
& { }^{236} \mathrm{Pu} \rightarrow{ }^{232} \mathrm{U} \rightarrow{ }^{228} \mathrm{Th} .
\end{aligned}
$$




\section{Conclusions}

Spent nuclear fuel contains a variety of neutron emitting nuclides. Most active neutron emitters are ${ }^{242} \mathrm{Cm}$ and ${ }^{244} \mathrm{Cm}$ nuclides.

The neutron emission in spent nuclear fuel of the RBMK-1500 type reactor is predominantly due to spontaneous fission products.

The total emission of neutrons generally decreases with time. Nevertheless, an increase of neutron emission from several nuclides can be observed during longterm storage of spent nuclear fuel. The increase is due to replenishment of the neutron emission-active nuclides from various decay chains.

\section{References}

[1] C.H. Le and G. Mathonniere, APOLLO1, Notice d'utilisation, Rapport DMT/SERMA/LERN (CEA, 1995).

[2] B. Duchemin, B. Nimal, and C. Raepsaet, Code REFACTN, Rapport DMT 95/111 (CEA, 1995).

[3] P. Reuss, Neutronique (INSTN, 1994).

[4] A.F. Henry, Nuclear Reactor Analysis (Massachusetts Institute of Technology, 1980).

[5] G. Adlys, D. Adlienè, and G. Bartkus, RBMK-1500 nuclear fuel with burnable absorber erbium, in: Proc. Int. Conf. Topfuel 2003 (Würzburg, 2003).

[6] A. Tanskanen, Assessment of the neutron and gamma sources of the spent BWR fuel (STUK, 2000).

\title{
NEUTRONŲ ŠALTINIAI RBMK-1500 REAKTORIAUS PANAUDOTAME BRANDUOLINIAME KURE
}

\author{
G. Adlys, D. Adlienè \\ Kauno technologijos universitetas, Kaunas, Lietuva
}

\begin{abstract}
Santrauka
Aptarta neutronu šaltinių, generuojamu RBMK-1500 reaktoriaus branduoliniame kure, ịtaka, ivvertinant radiacinę situaciją ivvairiuose branduolinio kuro saugojimo etapuose. Neutronu emisija sukelia papildomas dozines apkrovas personalui panaudoto branduolinio kuro laikymo bei transportavimo metu. Nagrinèti du pagrindiniai neutronu šaltiniai: neutronu emisija dèl aktinidu savaiminio dalijimosi ir neutronu emisija, vykstant $(\alpha, \mathrm{n})$ reakcijoms su branduolinio kuro oksidu deguonimi. Aktinidu susidarymas RBMK-1500 reaktoriaus kure modeliuotas naudojant programą APOLLO1, o neutronu emisijos intensyvumui iver-
\end{abstract}

tinti naudota programa REFACTN. Remiantis skaičiavimo rezultatais, galima nustatyti neutronu šaltinius îvairiais branduolinio kuro saugojimo etapais ir ịvertinti jų galią, kuri priklauso nuo kuro išdegimo, jo sudèties, pradinio isodrinimo, aušinimo trukmès. Taip pat, remiantis skaičiavimo rezultatais, parodyta, kad pagrindiniai neutronu šaltiniai RBMK-1500 reaktoriaus branduoliniame kure yra ${ }^{242,243,244} \mathrm{Cm},{ }^{236,238,240} \mathrm{Pu},{ }^{232} \mathrm{U},{ }^{241} \mathrm{Am}$, o jų emisijos intensyvumas, didejjant aušinimo trukmei, mažèja netolygiai. Paskutinioji išvada ypač svarbi prognozuojant radiacinę situaciją panaudoto branduolinio kuro saugyklos aplinkoje. 